internationalization do not always shed new light on the ways in which internationalization has changed or influenced academic work. Furthermore, analysis of survey data on the academic profession suggests that the internationalization of higher education may have been more rhetoric than reality, given limited changes to demographic patterns and faculty behaviors over the 15 years between 1992 and 2007.

What is clear, however, is that the international strategies of many institutions now envisage a holistic or comprehensive approach to internationalization across all areas of activity. These strategies assume the active involvement of faculty, although it remains to be seen whether faculty are motivated to adjust their work in response, and whether particular levers are likely to influence this next phase of faculty internationalization.

\section{Building an Inclusive Community for International Students}

\section{Rachawan Wongtrirat, Ravi Ammigan, And Adriana PÉreZ-ENCINAS}

Rachawan Wongtrirat is Assistant Director for International Education Initiatives in the Office of International Programs at the University of North Carolina, Charlotte, US. E-mail: rwongtri@uncc.edu. Ravi Ammigan is Director of the Office for International Students and Scholars at the University of Delaware, Newark, US. E-mail: rammigan@udel. edu. Adriana Pérez-Encinas is a lecturer and researcher in higher education and business organizations at the School of Business and Economics, Universidad Autónoma de Madrid, Spain. E-mail: adriana.perez. encinas@uam.es.

W ith the desire to connect campuses to the world, institutions of higher education are enrolling increasing numbers of international students, with a view to enhancing global perspectives and enriching the collegiate environment for the entire campus community. At the same time, the demand from the international student population has also increased. Project Atlas, conducted by the Institute of International Education, indicates that there were 2.I million international students worldwide in 200I, with international student enrollment doubling to 4.5 million by 20I2, representing an annual growth rate of almost 6 percent. Among the competitors for the global market share, the host countries with the highest number of enrolled international students were the United States $(886,052)$, the United Kingdom (48I,050), China $(356,499)$, France $(295,092)$, and Germany $(282,201)$. Although these numbers are good news for higher education at large, at an institutional level, international student enrollment often increases without adequate consideration of how the growth in enrollment will affect the campus capacities to serve and assist these students.

Enrolling international students, from either a degree mobility or credit mobility perspective, comes with institutional responsibilities regarding their development and success. The authors believe that international student support services and a positive international student co-curricular experience are essential for the successful creation of an inclusive community for international students. Although we may assume that a higher number of international enrollments would be better supported with enhanced international student support and services on a particular campus, this is not necessarily the case. The challenge to providing suitable services is that, although the international student population is conflated under the label "international students," there is great diversity among the students, who come from various countries around the world, and this needs to be taken into account.

\section{International Student Support Services}

Provision of student support services is of primary interest in the development of a strong international student program. With the number of internationally mobile students rapidly increasing, it is important that support services for these students grow similarly.

Successful management and operation of support services for international students can validate an institution's commitment to campus internationalization and to providing quality services. Internationalization itself is one indicator of quality in higher education, as Hans de Wit points out in the $201 \mathrm{I}$ book, Trends, Issues and Challenges in Internationalization of Higher Education, but it is not the only one. An institution that recognizes the value of enrolling international students on its campus must also recognize that it has an ethical responsibility to provide a range of support services that enhance international students' wellbeing and ensure their success. According to the European Union's Erasmus Impact Study (20I4), the increase in the number of incoming and outgoing students through Erasmus has led to an increased awareness of the necessity of providing support services and streamlining administrative procedures. At many universities, this has led to the establishment and/or further strengthening of support services for outgoing and incoming students.

There is a variety of organizational structures for international student support services and there is no one 
best model that each campus should follow. Some institutions trust that campus internationalization works best if international activities are united under one international umbrella, while others believe decentralization works best for their campus and political environment. Regardless of organizational structure, international education activities are generally the same across the board, although there are differences from country to country and from campus to campus. The authors argue that an institution should consider three factors that impact institutional support services for international students: hiring international education professionals, allocation of resources for program operation and management, and professional development for staff.

\section{InTERnational Student Co-CurRicular Experience}

An inclusive community refers to a community that provides a welcoming environment in which its members feel connected, safe, and experience a sense of belonging. Student engagement in co-curricular activities can be a powerful instrument that affects international students' sense of belonging and success. Many campuses, therefore, purposefully implement and develop student engagement programs, with the aim of building an inclusive community for

\section{Provision of student support services is of primary interest in the development of a strong international student pro- gram.}

international students. The authors argue that high-impact international student programming should be developed with at least two main objectives: international student engagement and retention; and international education and global connection. An administrator whose primary role is to respond to the needs of international students' extracurricular activities should consider four key components: cultural and social involvement, educational aspects, personal and/or professional development, and global leadership experience.

Examples of international student extra-curricular programming are clearly seen at Old Dominion University (US), the University of Delaware (US), and the Universidad Autónoma de Madrid (Spain). Programs focusing on international student engagement and retention include welcome receptions, field trips and excursions, weekly coffee hour, ice-cream socials, residence life mixers, and Erasmus socials. Educational programs at these three institutions include orientation programs, intercultural communication training, academic skills workshops, and athletics sessions. Personal/professional development programs include workshops on resumé writing, time management, study skills, employment options, and writing a research paper. Programs on global leadership experience include access to an international student advisory board and global mentorship. Other programs that focus on international education and global connection encompass international festivals, film screenings, and events celebrating local holiday traditions. Educational programs include global cafés, invited speakers, international education week, essay contests, and Erasmus in Schools programs. On the personal/professional development side, programs include presentations by international educators, university fairs, and events dealing with international etiquette. Global leadership experience is supported by global ambassadors programs and student leadership programs.

\section{CONCLUSION}

An inclusive international student community can be created as long as an institution is committed to developing a strong international student affairs environment on campus. Ultimately, an institution that desires to connect the campus to the world by enrolling international students must also help them succeed and retain them, in order to continue the engagement. Effective international student services and extra-curricular activities can be powerful and have a strong impact on international students' overall experience, development, and success. While focusing on services and program implementation and development, it is also important that international educators take account of student engagement by allowing international students to have input into the programs created for them. With experience, institutions have acquired more professionally trained staff, and allocated more offices and resources to support services and extra-curricular activities for international students. Finally, when evaluating services provided by international student support offices and when advocating future funding, it is important that international educators carry out critical assessment of international programs and the international student experience.

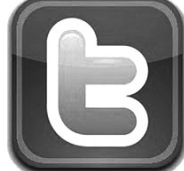

In addition to our Web site and Facebook page, we are now tweeting. We hope you will consider "following" us on Twitter! 